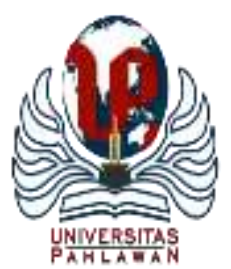

Edukatif : Jurnal Ilmu Pendidikan Volume 4 Nomor 1 Tahun 2022 Halm 323 - 337

EDUKATIF: JURNAL ILMU PENDIDIKAN

Research \& Learning in Education

https://edukatif.org/index.php/edukatif/index

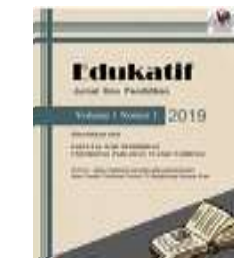

\title{
Pengaruh Lingkungan Sekolah dan Self-Efficacy terhadap Minat Melanjutkan Pendidikan ke Perguruan Tinggi Melalui Mediasi Prestasi Belajar
}

\author{
Heny Eka Sasmi ${ }^{1 凶}$, Achmad Fauzi $^{2}$, Mardi $^{3}$ \\ Universitas Negeri Jakarta, Indonesia ${ }^{1,2,3}$ \\ E-mail : henyekasasmi1997@gmail.com ${ }^{1}, \underline{\text { fauzifeunj@gmail.com }}^{2}$, mardifeunj2020@ gmail.com $^{3}$
}

\begin{abstract}
Abstrak
Penelitian ini bertujuan untuk mengetahui pengaruh lingkungan sekolah dan self-efficacy terhadap minat melanjutkan pendidikan ke perguruan tinggi melalui mediasi prestasi belajar pada siswa SMK program keahlian akuntansi keuangan lembaga di Kec.Kemayoran Jakarta Pusat tahun pelajaran 2020-2021. Data yang digunakan merupakan data kuantitatif metode proporsional random sampling dengan melihat tabel Issac \& Michael. Populasi dalam penelitian ini sebesar 180 orang dengan perolehan sampel sebesar 121 responden. Hipotesis diuji dengan menggunakan analisis jalur (path analysis) dan sobel test. Hasil penelitian pada model I diketahui lingkungan sekolah berpengaruh signifikan dan self-efficacy tidak berpengaruh signifikan terhadap prestasi belajar. Model II diketahui hasil lingkungan sekolah tidak berpengaruh signifikan, self-efficacy dan prestasi belajar berpengaruh signifikan terhadap minat melanjutkan pendidikan ke perguruan tinggi. Model III diketahui hasil lingkungan sekolah berpengaruh signifikan secara tidak langsung dan self-efficacy tidak berpengaruh signifikan secara tidak langsung terhadap minat melanjutkan pendidikan ke perguruan tinggi melalui mediasi prestasi belajar siswa.
\end{abstract}

Kata Kunci: Lingkungan Sekolah, Self-Efficacy, Minat Melanjutkan Pendidikan ke Perguruan Tinggi, Prestasi Belajar.

\begin{abstract}
This research aims to review the influence of the school environment and self-efficacy against interest in continuing education to college through mediation achievement study on a student will program accounting expertise financial institutions in central jakarta kec.kemayoran 2020-2021. The data used is quantitative proportional random sampling method with the formula issac\&michael table.The population in this study of 180 people by the acquisition of 121 respondent. Hypothesis tested with using analysis track (path analysis) and sobel test. The results of the study on the model I know the school self-efficacy significant and no significant impact on learning achievements. The II known the school environment not significant, selfefficacy and significant impact on learning achievements of interest in continuing education to college .Model III known the school environment significant indirectly self-efficacy and no significant indirectly of interest in continuing education to college students achievement by mediation .
\end{abstract}

Keywords: School Environment, Self-Efficacy, Continuing Education to College, Learning Achievement.

Copyright (c) 2022 Heny Eka Sasmi, Achmad Fauzi, Mardi

$\square$ Corresponding author

Email : henyekasasmi1997@gmail.com

DOI : https://doi.org/10.31004/edukatif.v4i1.1461

ISSN 2656-8063 (Media Cetak)

ISSN 2656-8071 (Media Online)

Edukatif : Jurnal Ilmu Pendidikan Vol 4 No 1 Tahun 2022 p-ISSN 2656-8063 e-ISSN 2656-8071 
324 Pengaruh Lingkungan Sekolah dan Self-Efficacy terhadap Minat Melanjutkan Pendidikan ke Perguruan Tinggi Melalui Mediasi Prestasi Belajar - Heny Eka Sasmi, Achmad Fauzi, Mardi

DOI: https://doi.org/10.31004/edukatif.v4i1.1461

\section{PENDAHULUAN}

Pendidikan dianggap sebagai salah satu parameter untuk melihat tumbuh kembang suatu negara, menjadikan pendidikan menjadi sesuatu yang wajib ditempuh. Sebab lewat pendidikan seseorang mampu mengubah taraf hidup dalam lingkup sosial serta perekonomian (Yuniarti, 2017). Industri 4.0 dengan segala sesuatu yang terbarukan, mendesak manusia untuk meningkatkan kualitasnya. Lewat pendidikan nasional diharapkan sanggup membentuk manusia profesional dan cakap dalam mengikuti perkembangan zaman (Nurjannah \& Kusmuriyanto, 2016). Jalur pendidikan di Indonesia terdiri dari pendidikan formal dan non formal. Sekolah Menengah Kejuruan (SMK) ialah salah satu jalur pendidikan formal yang berada pada tingkat kedua. Yang di dalamnya terdapat beragam program keahlian. Salah satu program keahlian tersebut adalah Akuntansi Keuangan Lembaga. Keahlian akuntansi bagi siswa Sekolah Menengah Kejuruan (SMK) berguna untuk meningkatkan ketrampilan serta keahlian pada siswa dalam mencatat, menggolongkan, mengikhtisarkan sekaligus memberitahukan suatu transaksi yang dipakai untuk membuat laporan keuangan. Lantaran ketrampilan dan keahlian yang dipelajari tersebut, siswa Sekolah Menengah Kejuruan (SMK) dituntut agar sanggup menentukan orientasi kariernya dengan dua opsi yaitu bekerja atau melanjutkan studi pendidikan ke perguruan tinggi (Mahyudin, 2019). Selama ini lulusan Sekolah Menengah Kejuruan (SMK) berorientasi untuk terjun ke dunia kerja. Namun berdasarkan data BPS periode 2018-2020 Tingkat Pengangguran Terbuka justru di dominasi oleh siswa SMK yang mana presentasenya terdiri dari 8,92\%,8,63\%, dan 8,49\%. Sehingga perlu dilakukan perbaikan dengan meningkatkan keahlian serta ketrampilan siswa SMK tersebut dengan cara melanjutkan Pendidikan ke perguruan tinggi.

Menurut Ahmad Susanto (2016) minat merupakan kecondongan jiwa seseorang terhadap suatu objek yang diiringi perasaan bahagia sebab merasa memiliki ketertarikan akan objek tersebut. Dalam hubungannya dengan aktivitas belajar minat dijadikan stimulus oleh individu dalam menggerakkan diri untuk melaksanakan sesuatu. Tanpa minat kegiatan belajar tidak akan berjalan lancar. Minat yang besar menjadi modal bagi seorang siswa untuk menggapai tujuan. Bila siswa mempunyai minat terhadap bidang pelajaran tertentu, akan membentuk pemahaman untuk belajar. Pemahaman siswa untuk belajar berpengaruh terhadap tumbuhnya kemauan untuk melanjutkan pendidikan ke perguruan tinggi dengan harapan menaikkan dan meningkatkan ilmu pengetahuan. Minat biasanya dinyatakan dalam wujud pastisipasi seseorang terhadap apa yang disukai. Minat erat kaitannya dengan dorongan dalam diri seseorang untuk berpartisipasi pada sesuatu aktivitas. Salah satu aspek yang mempengaruhi minat siswa dalam melanjutkan pendidikan ke perguruan tinggi adalah lingkungan sekolah.

Lingkungan sekolah terdiri dari 2 kata ialah lingkungan dan sekolah. Lingkungan secara luas bisa dimaksud sebagai tempat dimana personal manusia hidup serta berkehidupan yang berpengaruh serta pengaruhi komponen biotik dan abiotiknya untuk mengembangkan kompetensi personal manusia secara humanisme. Kemudian sekolah bisa di definisikan sebagai tempat untuk melaksanakan aktivitas belajar antara guru selaku pengajar dan siswa selaku partisipan, keduanya memiliki peran untuk mensukseskan tujuan belajar (Faliyandra, 2019). Dalam hal ini lingkungan sekolah sendiri teridri dari dua aspek yakni fisik dan sosial. Yang termasuk ke dalam lingkungan fisik sekolah adalah fasilitas sekolah, kondisi kelas, dan disiplin sekolah. Sedangkan yang termasuk ke dalam lingkungan sosial sekolah yakni semacam hubungan dengan guru dan antar siswa sekelas, dan karyawan sekolah yang berpengaruh terhadap proses belajar.

Tahun 2020 jadi tahun merebaknya Pandemi COVID-19 yang menyebar secara global. Salah satu akibat yang ditimbulkan dari adanya wabah tersebut ialah pergantian proses pembelajaran tatap muka yang beralih menjadi Pembelajaran Jarah Jauh (PJJ) atau School From Home (SFH). PJJ dijalankan oleh lembaga pendidikan di Indonesia dengan orientasi memberikan perlindungan serta keamanan bagi peserta didik dan tenaga pendidik guna memutus mata rantai penyebaran virus COVID-19. Konsekuensi yang didapatkan dari himbauan belajar di rumah adalah adanya perubahan interaksi antara guru serta siswa, siswa dengan siswa dari 
325 Pengaruh Lingkungan Sekolah dan Self-Efficacy terhadap Minat Melanjutkan Pendidikan ke Perguruan Tinggi Melalui Mediasi Prestasi Belajar - Heny Eka Sasmi, Achmad Fauzi, Mardi

DOI: https://doi.org/10.31004/edukatif.v4i1.1461

pembelajaran tatap muka berubah jadi pembelajaran daring sehingga proses interaksi dilakukan melalui media sosial dan platform pembelajaran online lainnya. Zoom, WA, Goggle Meet, Google Classroom salah satu media atau platform pembelajaran yang digunakan pihak sekolah untuk melaksanakan proses pembelajaran selama pandemi (Megawanti et al., 2020).

Faktor kedua yang di duga mempengaruhi minat siswa untuk melanjutkan studi ke perguruan tinggi adalah self-efficacy. Menurut Tri Anjaswari (2019) self-efficacy bisa dimasudkan sebagai kepercayaan atas keahlian diri untuk melaksanakan usaha terhadap suatu tugas yang sudah ditugaskan. Sebaliknya menurut Riyadi (2019) self-efficacy merupakan evaluasi orang akan kemampuan diri sendiri dalam merancang serta melakukan permulaan aktivitas yang disukai untuk memperolah unjuk kerja yang cocok dengan rencana. Selfefficacy bagi siswa berpengaruh dalam pemberian dorongan tenaga ataupun rangsangan untuk melaksanakan usaha melanjutkan studi (Kustiani et al., 2019). Kepercayaan orang atas keahlian yang dipunyai dalam melaksanakan usaha-usaha untuk melanjutkan pendidikan menentukan arah serta keputusan yang diambil siswa. Faktor berikutnya yang berpengaruh terhadap minat studi lanjut ke perguruan tinggi ialah prestasi belajar. Dalam hal ini prestasi belajar dapat dihubungkan dengan self-efficacy dan lingkungan sekolah karena keduanya turut andil dalam menentukan keberhasilan belajar siswa. Bagi Slameto (2019) prestasi belajar adalah statement mengenai fakta ketercapaian belajar yang diraih siswa berdasarkan standar kesuksesan sekolah, selepas satu satuan program pengalaman pembelajaran dalam satu watu periode tertentu. Kemudian menurut Kurniawati (2015) prestasi belajar ialah hasil dari suatu kegiatan baik secara individu maupun kelompok dalam satu waktu periode tertentu. Prestasi siswa bisa pengaruhi minat karena keduanya merupakan mata rantai yang tidak bisa putus. Siswa dengan minat besar akan berusaha untuk mendapatkan prestasi yang bagus. Prestasi yang bagus dapat mendorong siswa berkeinginan untuk melanjutkan pendidikan.

Semenjak bergabung dengan Programme for International Student Assesment (PISA) tahun 2000 kualitas pendidikan di indonesia mengalami kenaikan. PISA sendiri ialah studi internasional tentang literasi membaca, matematika serta sains yang mana kegiatannya dipelopori oleh Organisation of Economic Corporation and Development (OECD). Skor PISA Indonesia tahun 2015 dilihat dari keahlian membaca 397, keahlian matematika 386, dan keahlian kinerja sains 403. Hasil tersebut berbeda dengan hasil survei di 3 tahun sebelumnya yakni tahun 2018 yang mengalami penyusutan. Dimana keahlian membaca mendapatkan skor 371 menyusut 25 poin, keahlian matematika 379 menyusut 17 poin, dan keahlian kinerja sains 396 menyusut 7 poin. Melalui data tersebut diketahui penyusutan skor paling tinggi jatuh pada jenis atensi membaca sebanyak 25 poin.

Terdapat penelitian yang dilakukan oleh beberapa pakar dengan hasil berbeda. Penelitian Rahayu (2019) yang menyatakan jika variabel lingkungan sekolah tidak memiliki pengaruh signifikan terhadap minat siswa dalam melanjutkan pendidikan di perguruan tinggi. Perihal tersebut berarti semakin baik lingkungan sekolah belum tentu tinggi pula minat siswa untuk melanjutkan pendidikan ke perguruan tinggi. Hasil kebalikannya diungkapkan oleh Sakdiah (2018) yang berkata jika lingkungan sekolah punya pengaruh signifikan terhadap minat siswa dalam melanjutkan pendidikan di perguruan tinggi, perihal serupa pula diungkapkan oleh Nurjannah \& Kusmuriyanto (2016) jika lingkungan sosial sekolah mempunyai pengaruh signifikan terhadap minat studi lanjut pendidikan ke perguruan tinggi. Berikutnya penelitian yang dicoba oleh Defriyanto \& Sugiharta (2020) diperoleh hasil self-efficacy mempunyai pengaruh signifikan terhadap pengambilan keputusan siswa dalam melanjutkan pendidikan ke perguruan tinggi. Maksudnya semakin besar self-efficacy yang dipunyai individu maka semakin tinggi tingkat pengambilan keputusan dalam studi pendidikan ke perguruan tinggi, sebab tingginya self-efficacy mengindikasikan siswa mempunyai perencanaan dan strategi dalam pengambilan keputusan atas sesuatu yang diidamkan.

Berbeda dengan Cahyati \& Muchtar (2019) dalam penelitiannya diperoleh hasil jika prestasi belajar memiliki dampak yang tidak signifikan terhadap minat studi pendidikan ke perguruan tinggi. Kemudian menurut S. A. L. and Luchivya (2017) dan Gellor (2019) diperoleh hasil serupa yang mana dikatakan bahwa 
326 Pengaruh Lingkungan Sekolah dan Self-Efficacy terhadap Minat Melanjutkan Pendidikan ke Perguruan Tinggi Melalui Mediasi Prestasi Belajar - Heny Eka Sasmi, Achmad Fauzi, Mardi

DOI: https://doi.org/10.31004/edukatif.v4i1.1461

lingkungan sekolah berpengaruh signifikan terhadap prestasi belajar. Menurut Tomás et al (2020) mengungkapkan bahwa self-efficacy berpengaruh signifikan terhadap prestasi belajar siswa. Kebalikan hasil dari penelitian yang dilakukan oleh Roebianto (2020) menyimpulkan bahwa self-efficacy tidak memiliki pengaruh signifikan terhadap prestasi belajar .Penelitian oleh Barokah \& Yulianto (2019) yaitu lingkungan sekolah melalui prestasi belajar mempunyai pengaruh tidak langsung terhadap minat pelajar dalam merencanakan studi pendidikan ke perguruan tinggi. Tetapi perihal berbeda diungkapkan oleh Sofiyanti (2019) bersama fakta penelitian yang mengatakan self-efficacy mempunyai pengaruh tidak langsung terhadap minat siswa untuk studi pendidikan ke perguruan tinggi.

Berdasarkan latar belakang permasalahan yang telah dipaparkan peneliti, diketahui bahwa hasil dari setiap penelitian yang dilakukan oleh beberapa ahli diperoleh hasil berbeda. Selain itu ditemukan beberapa permasalahan yaitu adanya kesenjangan antara kondisi yang diharapakan dengan realita yang mempengaruhi minat siswa dalam melanjutkan pendidikan ke perguruan tinggi. Melalui penelitian ini peneliti ingin mengetahui seberapa besar dampak prestasi belajar dalam mempengaruhi minat siswa dalam melanjutkan pendidikannya ke perguruan tinggi. Oleh karena itu peneliti tartarik untuk melakukan penelitian dengan judul "Pengaruh Lingkungan Sekolah dan Self-Efficacy Terhadap Minat Melanjutkan Pendidikan Ke Perguruan Tinggi Melalui Mediasi Prestasi Belajar Siswa SMK Program Keahlian Akuntansi Keuangan Lembaga Jakarta Pusat".

\section{METODE PENELITIAN}

Penelitian ini merupakan penelitian kuantitatif. Penelitian kuantitatif merupakan penelitian yang memiliki nama lain sebagai penelitian tradisional yang berlandaskan pada filsafat positivisme yang meneliti pada sejumlah sampel atau populasi tertentu (Sugiyono, 2013). Populasi dalam penelitian ini adalah siswa kelas XII SMK Negeri yang ada di Jakarta Pusat Kec.Kemayoran program keahlian Akuntansi Keuangan Lembaga (AKL) sebanyak 180 siswa. Teknik pengambilan sampel yakni proporsional random sampling dengan melihat table issac \& Michael (Puspitaningtyas, 2012), sehingga diperoleh sampel sebayak 121 siswa. Teknik pengumpulan data dengan menggunakan skala likert untuk variabel X1, X2, Y dengan rentang skor 15. Sedangkan untuk varibael mediasi $\mathrm{Z}$ data diperoleh melalui data sekunder yaitu nilai rapot siswa kelas 12 semester genap . Model konseptual dalam penelitian ini dapat dilihat melalui gambar di bawah ini :

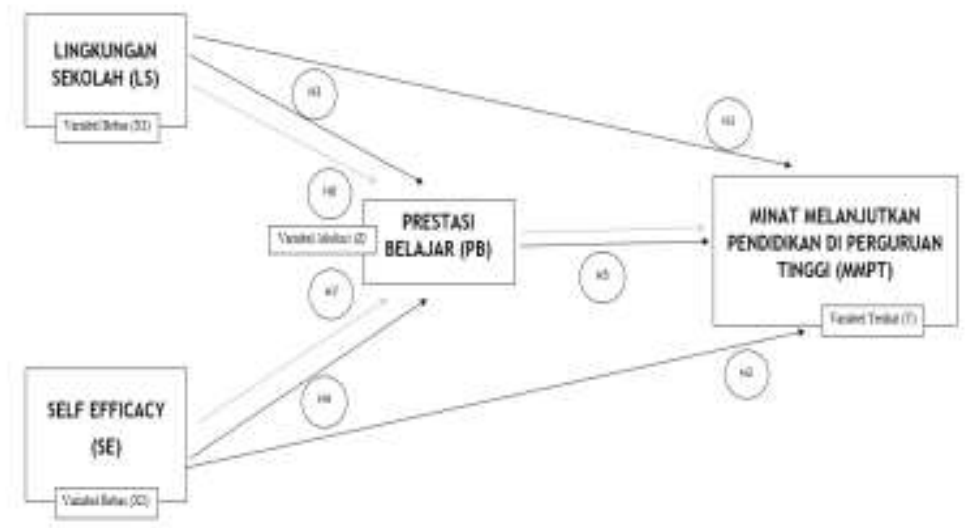

Gambar 1 Model Konseptual Penelitian

Keterangan:

Lingkungan Sekolah $(\mathrm{LS})-\left(\mathrm{X}_{1}\right)$

Self-Efficacy (SEC) $-\left(\mathrm{X}_{2}\right)$

Minat Melanjutkan Pendidikan
: Variabel Eksogen

: Variabel Eksogen 
327 Pengaruh Lingkungan Sekolah dan Self-Efficacy terhadap Minat Melanjutkan Pendidikan ke Perguruan Tinggi Melalui Mediasi Prestasi Belajar - Heny Eka Sasmi, Achmad Fauzi, Mardi

DOI: https://doi.org/10.31004/edukatif.v4i1.1461

ke Perguruan Tinggi (MMPT) - (Y)

Prestasi Belajar (PB) - (Z)
: Variabel Endogen

: Variabel Mediasi

: Arah Hubungan

Uji coba data dilakukan dengan dua analisis data menggunakan aplikasi SPSS 24. Terdiri dari dua uji 1) uji validitas, uji validitas digunakan untuk mengukur indikator yang digunakan dalam sebuah penelitian apakah sudah mewakili variabel penelitian yang digunakan peneliti. Dikatakan valid apabila nilai dari r-tabel kecil dari r-hitung. 2) uji reliabilitas merupakan suatu uji yang dilakukan guna mengetahui tingkat kehandalan (kepercayaan) suatu item pertanyaan untuk mengukur variabel yang diteliti. Data dikatakan reliabel apabila memiliki tingkat kehandalan yang tinggi (Priyono, 2008).

\section{HASIL DAN PEMBAHASAN PENELITIAN}

\section{Hasil uji coba instrumen penelitian}

Uji coba penelitian dilakukan pada 30 orang siswa SMK kelas 12 program keahlian Otomatisai \& Tata Kelola Perkantoran (OTKP). Jumlah keseluruha item butir pernyataan untuk 3 variabel penelitian adalah 60 . Sehingga pada uji penelitian final diperoleh total keseluruhan butir pernyataan sebanyak 53 butir yang terdiri dari 18 butir pernyataan variabel (LS), 19 butir pernyataan variabel (SEC), dan 18 butir pernyataan untuk variabel (MMPT).

\section{Hasil Uji Prasyarat Analisis}

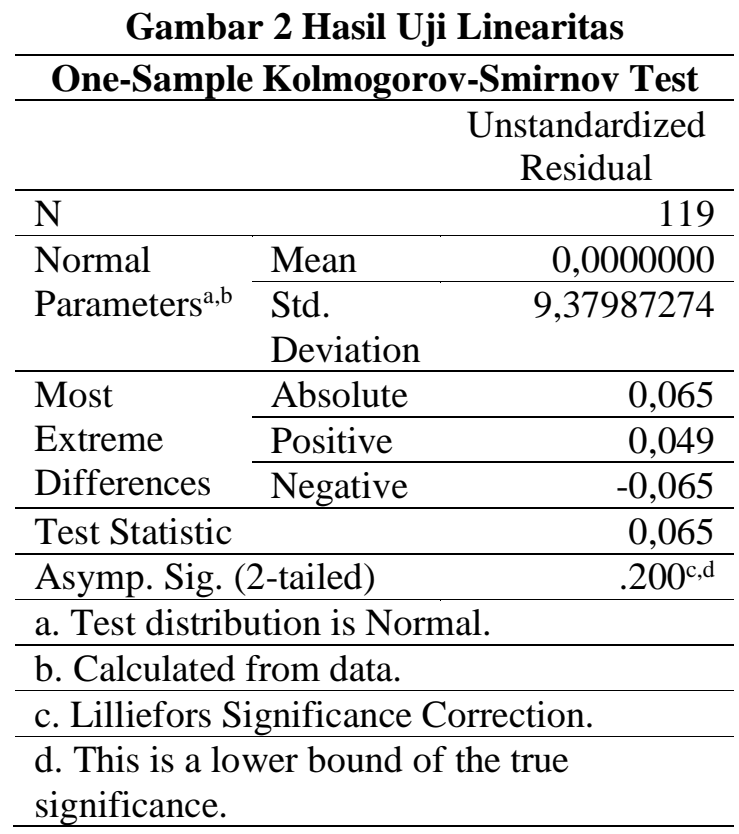

Keputusan yang diambil dalam penelitian ini dengan melihat nilai Asym.Sig pada tabel di atas yakni sebesar 0,200. Hal tersebut dapat disimpulkan bahwa data dinyatakan memiliki distribusi normal karena 0,200 besar dari 0,05. Sehingga data penelitian bebas dari pengaruh normalitas 
328 Pengaruh Lingkungan Sekolah dan Self-Efficacy terhadap Minat Melanjutkan Pendidikan ke Perguruan Tinggi Melalui Mediasi Prestasi Belajar - Heny Eka Sasmi, Achmad Fauzi, Mardi

DOI: https://doi.org/10.31004/edukatif.v4i1.1461

Tabel 1 Hasil Uji Linearitas $X_{1}$ dan $Y$

\begin{tabular}{|c|c|c|c|c|c|c|c|}
\hline \multicolumn{8}{|c|}{ ANOVA Table } \\
\hline & & & $\begin{array}{c}\text { Sum of } \\
\text { Squares }\end{array}$ & df & $\begin{array}{c}\text { Mean } \\
\text { Square }\end{array}$ & $\mathbf{F}$ & Sig. \\
\hline \multirow{5}{*}{$\begin{array}{l}\text { Continuing } \\
\text { to College * } \\
\text { School } \\
\text { Environment }\end{array}$} & Between & (Combined) & 3861,626 & 38 & 101,622 & 1,066 & 0,397 \\
\hline & Groups & Linearity & 201,747 & 1 & 201,747 & 2,115 & 0,150 \\
\hline & & $\begin{array}{l}\text { Deviation } \\
\text { from } \\
\text { Linearity }\end{array}$ & 3659,880 & 37 & 98,916 & 1,037 & 0,435 \\
\hline & Within ( & roups & 7629,533 & 80 & 95,369 & & \\
\hline & Total & & 11491,160 & 118 & & & \\
\hline
\end{tabular}

Uji linearitas pertama dengan melihat kolom deviation from linearity diperoleh fhitung sebesar 1,037 kecil dari ftabel 4,11. Disimpulkan ada hubungan yang linear antara lingkungan sekolah (X1) dan minat melanjutkan pendidikan ke perguruan tinggi (Y).

Tabel 2 Hasil Uji Linearitas $\mathbf{X}_{2}$ dan $Y$

\begin{tabular}{|c|c|c|c|c|c|c|c|}
\hline \multicolumn{8}{|c|}{ ANOVA Table } \\
\hline & & & $\begin{array}{c}\text { Sum of } \\
\text { Squares }\end{array}$ & df & $\begin{array}{l}\text { Mean } \\
\text { Square }\end{array}$ & $\mathbf{F}$ & Sig. \\
\hline \multirow{5}{*}{$\begin{array}{l}\text { Continuing } \\
\text { to College * } \\
\text { Self- } \\
\text { Efficacy }\end{array}$} & \multirow{3}{*}{$\begin{array}{c}\text { Between } \\
\text { Groups }\end{array}$} & (Combined) & 3490,692 & 32 & 109,084 & 1,173 & 0,277 \\
\hline & & Linearity & 565,374 & 1 & 565,374 & 6,077 & 0,016 \\
\hline & & $\begin{array}{l}\text { Deviation } \\
\text { from } \\
\text { Linearity }\end{array}$ & 2925,319 & 31 & 94,365 & 1,014 & 0,462 \\
\hline & \multicolumn{2}{|c|}{ Within Groups } & 8000,467 & 86 & 93,029 & & \\
\hline & Total & & 11491,160 & 118 & & & \\
\hline
\end{tabular}

Uji linearitas kedua dengan melihat kolom deviation from linearity diperoleh fhitung sebesar 1,037 kecil dari ftabel 4,16. Disimpulkan ada hubungan yang linear antara self-efficacy (X2) terhadap minat melanjutkan pendidikan ke perguruan tinggi (Y).

Tabel 3 Hasil Uji Linearitas Z dan Y

\begin{tabular}{|c|c|c|c|c|c|c|c|}
\hline \multicolumn{8}{|c|}{ ANOVA Table } \\
\hline & & & $\begin{array}{c}\text { Sum of } \\
\text { Squares }\end{array}$ & df & $\begin{array}{c}\text { Mean } \\
\text { Square }\end{array}$ & $\mathbf{F}$ & Sig. \\
\hline \multirow{5}{*}{$\begin{array}{l}\text { Continuing to } \\
\text { College * } \\
\text { Learning } \\
\text { Achievement }\end{array}$} & \multirow{3}{*}{$\begin{array}{l}\text { Between } \\
\text { Groups }\end{array}$} & (Combined) & 1580,523 & 10 & 158,052 & 1,722 & 0,085 \\
\hline & & Linearity & 570,882 & 1 & 570,882 & 6,221 & 0,014 \\
\hline & & $\begin{array}{l}\text { Deviation } \\
\text { from } \\
\text { Linearity }\end{array}$ & 1009,642 & 9 & 112,182 & 1,222 & 0,289 \\
\hline & \multicolumn{2}{|c|}{ Within Groups } & 9910,636 & 108 & 91,765 & & \\
\hline & \multicolumn{2}{|l|}{ Total } & 11491,160 & 118 & & & \\
\hline
\end{tabular}

Uji linearitas kedua dengan melihat kolom deviation from linearity diperoleh fhitung sebesar 1,222 kecil dari ftabel 5,12. Disimpulkan ada hubungan yang linear antara prestasi belajar (Z) dan minat melanjutkan pendidikan ke perguruan tinggi (Y). 
329 Pengaruh Lingkungan Sekolah dan Self-Efficacy terhadap Minat Melanjutkan Pendidikan ke Perguruan Tinggi Melalui Mediasi Prestasi Belajar - Heny Eka Sasmi, Achmad Fauzi, Mardi

DOI: https://doi.org/10.31004/edukatif.v4i1.1461

\section{Analisis Regresi Berganda}

Tabel 4 Analisis Regresi Berganda Model I

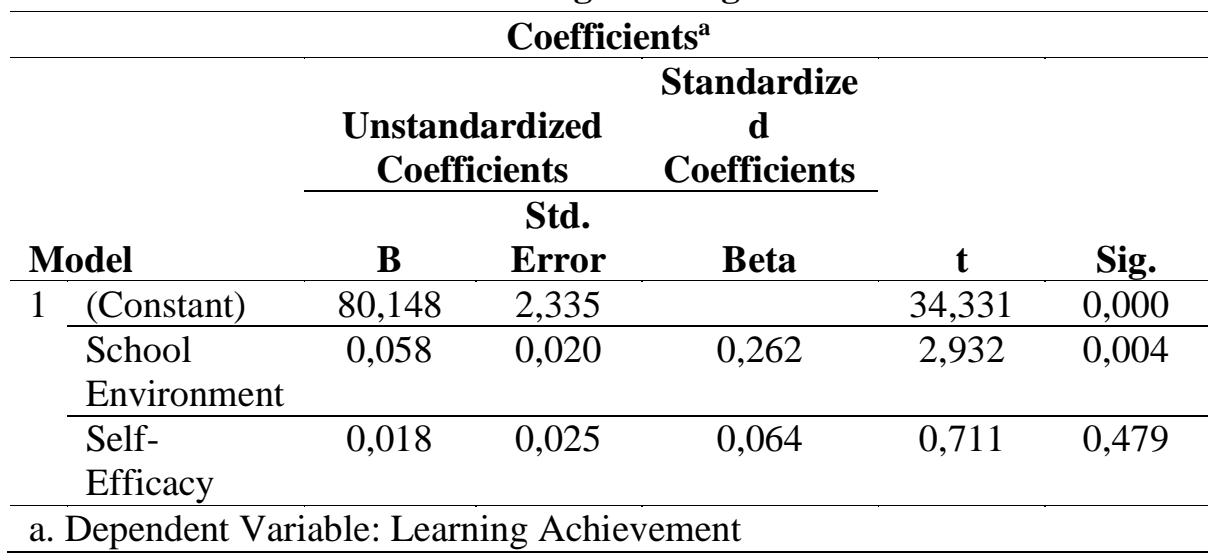

Berdasarkan tabel di atas, diketahui persamaan regresi yang dihasilkan untuk model yang pertama adalah :

$$
\begin{gathered}
Z=a_{1}+b_{1} x_{1_{+}} b_{2} x_{2} \\
Z=80,148+0,058 x_{1_{+}} 0,18 x_{2}
\end{gathered}
$$

Hasil di atas menunjukkan bahwa nilai konstanta ${ }^{a_{1}}$ sebesar 80,148. Apabila nilai lingkungan sekolah (X1), self-efficacy (X2) bernilai 0, maka variabel prestasi belajar akan bernilai 80,148. Artinya apabila variabel lingkungan sekolah mengalami kenaikan sebesar satu nilai pada kosntanta 80,248 dengan asumsi self-efficacy (X2) bernilai tetap maka prestasi belajar akan mengalami peningkatan sebesar 0,58. Berikutnya self-efficacy, jika mengalami kenaikan sebasar satu nilai pada kosntanta 80,248 dengan asumsi lingkungan sekolah (X1) bernilai tetap maka prestasi belajar akan mengalami peningkatan sebesar 0,18 .

\begin{tabular}{|c|c|c|c|c|c|}
\hline \multirow[b]{3}{*}{ Model } & \multicolumn{4}{|c|}{ Coefficients $^{\mathbf{a}}$} & \multirow[b]{3}{*}{ Sig. } \\
\hline & \multicolumn{2}{|c|}{$\begin{array}{c}\text { Unstandardized } \\
\text { Coefficients }\end{array}$} & \multirow{2}{*}{$\begin{array}{c}\begin{array}{c}\text { Standardize } \\
\text { d } \\
\text { Coefficients }\end{array} \\
\text { Beta } \\
\end{array}$} & \multirow[b]{2}{*}{ t } & \\
\hline & B & $\begin{array}{c}\text { Std. } \\
\text { Error }\end{array}$ & & & \\
\hline 2 (Constant) & $-23,312$ & 35,126 & & $-0,664$ & 0,508 \\
\hline $\begin{array}{l}\text { School } \\
\text { Environment }\end{array}$ & 0,072 & 0,092 & 0,072 & 0,779 & 0,437 \\
\hline Self-Efficacy & 0,263 & 0,115 & 0,203 & 2,287 & 0,024 \\
\hline $\begin{array}{l}\text { Learning } \\
\text { Achievement }\end{array}$ & 0,854 & 0,418 & 0,188 & 2,041 & 0,044 \\
\hline
\end{tabular}

Tabel 5 Tabel Analisis Regresi Berganda Model II

Berdasarkan tabel di atas, diketahui persamaan regresi yang dihasilkan untuk model kedua adalah :

$$
\begin{gathered}
Y=a_{2}+b_{1} X_{1_{+}} b_{2} X_{2} Z \\
Y=-23.312+0,072 x_{1_{+}} 0,263 x_{2} 0,854
\end{gathered}
$$

Hasil di atas menunjukkan bahwa nilai konstanta $a_{1}$ sebesar -23,312. Artinya apabila variabel lingkungan sekolah (X1) mengalami kenaikan sebesar satu nilai, maka minat melanjutkan pendidikan ke 
330 Pengaruh Lingkungan Sekolah dan Self-Efficacy terhadap Minat Melanjutkan Pendidikan ke Perguruan Tinggi Melalui Mediasi Prestasi Belajar - Heny Eka Sasmi, Achmad Fauzi, Mardi

DOI: https://doi.org/10.31004/edukatif.v4i1.1461

perguruan tinggi akan mengalami peningkatan senilai 0,072 pada kosntanta $-23,312$ dengan asumsi selfefficacy (X2) dan prestasi belajar (Z) bernilai tetap. Berikutnya jika self-efficacy mengalami kenaikan sebasar satu nilai pada konstanta -23,312 maka minat melanjutkan pendidikan ke perguruan tinggi akan mengalami peningkatan senilai 0,263 dengan asumsi lingkungan sekolah (X1) dan prestasi belajar (Z) bernilai tetap. Terakhir jika prestasi belajar mengalami kenaikan sebasar satu nilai maka minat melanjutkan pendidikan ke perguruan tinggi akan meningkat senilai 0,854 pada kosntanta -23,312 dengan asumsi lingkungan sekolah (X1) dan self-efficacy (X2) memiliki nilai tetap.

\section{Analisis Jalur (Path Analysis)}

\section{Jalur Model 1 Pengaruh Lingkungan Sekolah dan Self-Efficacy terhadap Prestasi Belajar}

Melalui tabel persamaan regresi diperoleh infromasi bahwa besar pengaruh Lingkungan Sekolah $\left(\mathrm{X}_{1}\right)$ sebesar 0,058 atau 5,8\% terhadap Prestasi Belajar (Z), kemudian besar pengaruh Self-Efficacy $\left(\mathrm{X}_{2}\right)$ 0,018 atau $1,8 \%$ terhadap Prestasi Belajar $(Z)$. Diperoleh nilai e1 $=\sqrt{(1-0,075)}$ sebesar 0,961 .

Tabel 6 Model Summary I

\begin{tabular}{|c|c|c|c|c|}
\hline \multicolumn{5}{|c|}{ Model Summary } \\
\hline Model & $\mathbf{R}$ & R Square & $\begin{array}{l}\text { Adjusted } \\
\text { R Square }\end{array}$ & $\begin{array}{l}\text { Std. Error } \\
\text { of the } \\
\text { Estimate }\end{array}$ \\
\hline 1 & $.273^{\mathrm{a}}$ & 0,075 & 0,059 & 2,10960 \\
\hline \multicolumn{5}{|c|}{$\begin{array}{l}\text { a. Predictors: (Constant),Self-Efficacy (X2), School } \\
\text { Environment (XI) }\end{array}$} \\
\hline b. Dep & at Var & : Learning & hievement & \\
\hline
\end{tabular}

Pengaruh tidak langsung Lingkungan Sekolah terhadap Minat Melanjutkan Pendidikan ke Perguruan Tinggi Melalui Mediasi Prestasi Belajar

Pengaruh tidak langsung dari Lingkungan Sekolah $\left(\mathrm{X}_{1}\right)$ terhadap Minat Melanjutkan Pendidikan ke Perguruan Tinggi $(\mathrm{Y})$ melalui Prestasi Belajar $(\mathrm{Z})$ adalah $(0,058 \times 0,854)=0,049$ atau 4,9\%. Jadi total pengaruh Lingkungan Sekolah $\left(\mathrm{X}_{1}\right)$ terhadap Minat Melanjutkan Pendidikan ke Perguruan Tinggi $(\mathrm{Y})$ adalah $(0,072+0,049)=0,121$ atau $12,1 \%$.

\section{Jalur Model 2 Pengaruh Lingkungan Sekolah (X1) dan Self-Efficacy (X2) terhadap Minat Melanjutkan Pendidikan ke Perguruan Tinggi}

Melalui tabel persamaan regresi diperoleh infromasi bahwa besar pengaruh Lingkungan Sekolah $\left(\mathrm{X}_{1}\right)$ 0,072 atau 7,2\% terhadap Minat Melanjutkan Pendidikan ke Perguruan Tinggi (Y), kemudian besar pengaruh Self-Efficacy $\left(\mathrm{X}_{2}\right)$ 0,263 atau 26,3\% terhadap Minat Melanjutkan Pendidikan ke Perguruan Tinggi (Y). Dan besar pengaruh Prestasi Belajar (Z) terhadap Minat Melanjutkan Pendidikan ke Perguruan Tinggi (Y) adalah 0,854 atau $85,4 \%$.

Tabel 7 Model Summary II

\begin{tabular}{|c|c|c|c|c|}
\hline \multicolumn{5}{|c|}{ Model Summary $^{b}$} \\
\hline Model & $\mathbf{R}$ & $\begin{array}{c}\mathbf{R} \\
\text { Square }\end{array}$ & $\begin{array}{l}\text { Adjusted } \\
\text { R Square }\end{array}$ & $\begin{array}{l}\text { Std. Error } \\
\text { of the } \\
\text { Estimate }\end{array}$ \\
\hline 2 & $.311^{\mathrm{a}}$ & 0,097 & 0,073 & 9,501 \\
\hline \multicolumn{5}{|c|}{$\begin{array}{l}\text { a. Predictors: (Constant), Learning Achievement, Self- } \\
\text { Efficacy, School Environment }\end{array}$} \\
\hline b. Depe & Variab & Continuin & to College & \\
\hline
\end{tabular}


331 Pengaruh Lingkungan Sekolah dan Self-Efficacy terhadap Minat Melanjutkan Pendidikan ke Perguruan Tinggi Melalui Mediasi Prestasi Belajar - Heny Eka Sasmi, Achmad Fauzi, Mardi

DOI: https://doi.org/10.31004/edukatif.v4i1.1461

\section{Pengaruh tidak langsung Self-Efficacy (SE) terhadap Minat Melanjutkan Pendidikan ke Perguruan Tinggi Melalui Mediasi Prestasi Belajar}

Pengaruh tidak langsung dari Self-Efficacy $\left(\mathrm{X}_{2}\right)$ terhadap Minat Melanjutkan Pendidikan ke Perguruan Tinggi (Y) melaluii mediasi Prestasi Belajar $(\mathrm{Z})$ adalah $(0,018 \times 0,854)=0,015$ atau 1,5\%. Jadi total pengaruh Self-Efficacy $\left(\mathrm{X}_{2}\right)$ terhadap Minat Melanjutkan Pendidikan ke Perguruan Tinggi $(\mathrm{Y})$ adalah $(0,263+0,015)=$ 0,278 atau $27,8 \%$

\section{Pengaruh Lingkungan Sekolah terhadap Minat Melanjutkan Pendidikan ke Perguruan Tinggi} ditolak

Hasil perhitungan uji t diperoleh nilai sebesar 0,437 yang artinya besar dari 0,05. Disimpulkan $\mathrm{H}_{1}$ pendidikan ke perguruan tinggi. Penelitian ini selaras dengan penelitian yang dilakukan oleh (Rahayu, 2019) di dapatkan hasil bahwa lingkungan sekolah tidak memiliki pengaruh terhadap minat melanjutkan pendidikan ke perguruan tinggi perhitungan taraf signifikansi 0,221 besar dari 0,05. Hasil tersebut juga di dukung oleh penelitian yang dilakukan oleh (Agustina, 2018) dengan hasil $\mathrm{t}_{\text {hitung }}$ 1,812 kecil dari 6,501. Penelitian tersebut menjelaskan bahwa lingkungan sekolah tidak berpengaruh terhadap minat untuk melanjutkan pendidikan ke perguruan tinggi di karenakan siswa menganggap sumbangsih sekolah dalam mempengaruhi minat untuk studi dalam kategori sedang. Lingkungan sekolah dalam hal ini meliputi interaksi dan hubungan guru dengan siswa di sekolah berlangsung tanpa mempengaruhi minat siswa untuk studi lanjut.

Kondisi lingkungan sekolah yang mengalami transisi setelah penyebaran virus COVID-19 menyebabkan kegiatan belajar tatap muka beralih menjadi pembelajaran secara daring. Hal ini berpengaruh terhadap sosialisasi sekolah dalam mendukung siswa untuk studi lanjut. Berakibat siswa merasa kurang optimalnya dukungan dari lingkungan sekolah dalam memberikan informasi mengenai perguruan tinggi. Sehingga banyak siswa merasa bahwa kebutuhan akan informasi terhadap perguruan tinggi masih belum cukup terpenuhi. Dalam kasus ini siswa beranggapan bahwa perolehan informasi serta pengalaman mengenai perguruan tinggi bukan hanya bisa diperoleh melalui sekolah akan tetapi bisa juga di dapatkan melalui teman sebaya, keluarga, atau orang lain. Pemaparan beberapa hasil penelitian diatas menegaskan bahwa lingkungan sekolah tidak memiliki pengaruh signifikan terhadap minat siswa untuk melanjutkan pendidikan ke perguruan tinggi.

Selain itu pada penelitian (Siti Khadijah, Henny Indrawati, 2017) di dapatkan hasil yang sama. Dijelaskan bahwa lingkungan sekolah berpengaruh tidak signifikan terhadap minat untuk studi lanjut dikarenakan alumni kurang memberikan gambaran positif mengenai pergururan tinggi tempat mereka berkuliah, alumni yang tidak mendapatkan pekerjaan yang layak setelah lulus dari perguruan tinggi. Atau juga bisa disebabkan karena teman-teman yang tidak melanjutkan studi yang kemudian mempengaruhi keberlangsungan minat siswa dalam studi lanjut.Bertolak belakang perolehan penelitian (Qahfi et al., 2020) menyatakan bahwa ada pengaruh signifikan variabel lingkungan sekolah terhadap minat melanjutkan pendidikan ke perguruan tinggi, dikatakan bahwa lingkungan sekolah mempunyai peranan dalam mempengaruhi seorang siswa untuk melanjutkan pendidikan ke perguruan tinggi.

Pemaparan beberapa hasil penelitian diatas menegaskan bahwa lingkungan sekolah memiliki pengaruh positif dan tidak signifikan terhadap minat siswa untuk melanjutkan pendidikan ke perguruan tinggi.

\section{Pengaruh Self-Efficacy terhadap Minat Melanjutkan Pendidikan ke Perguruan Tinggi}

Hasil perhitungan uji $\mathrm{t}$ diperoleh nilai signifikansi sebesar 0,024 kecil dari 0,05. Disimpulkan $\mathrm{H}_{2}$ diterima, sehingga variabel self-efficacy memiliki pengaruh yang signifikan terhadap minat melanjutkan pendidikan ke perguruan tinggi. Teori dalam hasil penelitian ini sesuai dengan Ajzen (1991) yang menyatakan bahwa perilaku seseorang tergantung pada keinginan. Kontrol dari perilaku ini akan mengendalikan 
332 Pengaruh Lingkungan Sekolah dan Self-Efficacy terhadap Minat Melanjutkan Pendidikan ke Perguruan Tinggi Melalui Mediasi Prestasi Belajar - Heny Eka Sasmi, Achmad Fauzi, Mardi

DOI: https://doi.org/10.31004/edukatif.v4i1.1461

bagaimana tindakan seseorang untuk mengambil kesempatan dalam mewujudkan keinginan. Salah satu yang berpengaruh terhadap kontrol diri dalam melakukan sebuah tindakan adalah self-efficacy. Dimana self-efficacy ini sendiri merupakan keyakinan akan diri seseorang terhadap kemampuan yang dimiliki. Menurut (Bandura, 1995) dijelaskan bahwa self-efficacy menjadi salah satu faktor yang mempengaruhi seseorang untuk melanjutkan pendidikan ke perguruan tinggi. Tingginya self-efficacy yang dimiliki oleh seorang siswa dapat mempengaruhi tingginya minat studi. Kondisi demikian dipersepsikan dapat menumbuhkan ketertarikan untuk meraih tujuan.

Penelitian ini selaras dengan penelitian yang dilakukan oleh (Defriyanto \& Sugiharta, 2020) yang mana self-efficacy memiliki pengaruh kuat terhadap minat siswa untuk melanjutkan pendidikan ke perguruan tinggi. Dimana perolehan nilai korelasi antara variabel self-efficacy terhadap minat melanjutkan pendidikan ke perguruan tinggi dalam kategori tinggi yakni besar 0,628. Dukungan atas hasil penelitian serupa di kemukakan (Lase, 2020) yang menyatakan bahwa self-eeficacy memiliki pengaruh positif dan signifikan. Senada dengan keduanya (Subarkah \& Nurkhin, 2018) dan (Kustiani et al., 2019) yang menyatakan bahwa self-efficacy mempunyai pengaruh signifkan. Penelitian (Hanim \& Puspasari, 2021) memaparkan self-efficacy yang tinggi akan meningkatkan kepercayaan diri dalam diri individu untuk melanjutkan studi dan mnegenyam jejang Pendidikan lebih tinggi. Semakin bagus tingkat self-efficacy diri siswa akan meningkatkan minat siswa untuk melanjutkan studinya. Sebaliknya semakin rendah self-efficacy diri siswa akan berpengaruh terhadap minat untuk melanjutkan pendidikan ke perguruan tinggi.

Pemaparan beberapa hasil penelitian diatas menegaskan bahwa self-efficacy memiliki pengaruh positif dan signifikan terhadap minat siswa untuk melanjutkan pendidikan ke perguruan tinggi.

\section{Pengaruh Prestasi Belajar terhadap Minat Melanjutkan Pendidikan ke Perguruan Tinggi}

Hasil perhitungan uji t diperoleh nilai signifikansi sebesar 0,044 besar dari 0,05. Disimpulkan $\mathrm{H}_{3}$ diterima, sehingga variabel prestasi belajar memiliki pengaruh signifikan. terhadap minat melanjutkan pendidikan ke perguruan tinggi. Penelitian ini selaras dengan (Nurjannah \& Kusmuriyanto, 2016) dengan perolehan hasil penelitian yang menyatakan ada pengaruh prestasi belajar siswa terhadap minat siswa untuk studi lanjut. Dijelaskan bahwa salah satu potensi diri yang ada dalam diri siswa akan mempengaruhi prestasi belajar siswa, sehingga prestasi belajar yang baik akan meningkatkan minat siswa untuk melanjutkan studi ke perguruan tinggi. Selanjutnya menurut Ajzen dalam (Barokah \& Yulianto, 2019) mengenai teori perilaku terencana. Pada penelitian ini perilaku yang dimaksudkan di asumsikan sebagai variabel prestasi belajar. Prestasi merupakan hasil dari perilaku seseorang untuk mencapai suatu tujuan. Sehingga perilaku siswa yang mengusahakan mendapat prestasi yang bagus akan berpengaruh terhadap minat siswa untuk melanjutkan studi.

Dalam (Amiqul \& Rediana, 2016) diapaprkan hasil prestasi berpengaruh terhadap minat studi. Berikutnya dalam (Saputra, 2015) diungkapkan hal senada yang menyatakan bahwa prestasi punya pengaruh signifikan dimana semakin baik prestasi seorang siswa akan meningkatkan minat siswa untuk melanjutkan studinya. Sebaliknya apablia prestasi yang dimiliki oleh diri siswa rendah akan menurunkan minat siswa untuk melanjutkan studi. Bertolah belakang dengan beberapa ahli, dipaparkan oleh (Cahyati \& Muchtar, 2019) yang memaparkan bahwa minat melanjutkan pendidikan ke perguruan tinggi tidak dipengaruhi oleh prestasi belajar. Pemaparan hasil penelitian diatas menegaskan bahwa prestasi belajar memiliki pengaruh positif dan signifikan terhadap minat siswa untuk melanjutkan pendidikan ke perguruan tinggi. Dapat disimpulkan bahwa semakin baik prestasi seseorang makan akan meningkatkan minat siswa untuk melanjutkan pendidikan ke perguruan tinggi. Kepercayaan diri siswa akan meningkat untuk masuk perguruan tinggi karena menganggap dirinya mempunyai kemampuan. Kemampuan tersebut digambarkan melalui prestasi belajar siswa yang di dapatkan setelah proses belajar yang dilakukan selama satuan semester. 
333 Pengaruh Lingkungan Sekolah dan Self-Efficacy terhadap Minat Melanjutkan Pendidikan ke Perguruan Tinggi Melalui Mediasi Prestasi Belajar - Heny Eka Sasmi, Achmad Fauzi, Mardi

DOI: https://doi.org/10.31004/edukatif.v4i1.1461

Pemaparan beberapa hasil penelitian diatas menegaskan bahwa prestasi belajar memiliki pengaruh positif dan signifikan terhadap minat siswa untuk melanjutkan pendidikan ke perguruan tinggi.

\section{Pengaruh Lingkungan Sekolah terhadap Prestasi Belajar}

Hasil perhitungan uji t diperoleh signifikansi sebesar 0,004 besar dari 0,05. Disimpulkan $\mathrm{H}_{4}$ diterima, yang artinya variabel lingkungan sekolah memiliki pengaruh signifikan terhadap prestasi belajar. Penelitian ini dapat dihubungkan dengan teori konvergensi yang dipelopori oleh Louis William Stern (1871-1938). Dipaparkan bahwa manusia itu unik. Keunikan yang ada pada diri menusia menghadirkan potensi yang berbeda. Berarti keunikan yang dimiliki oleh masing-masing individu tidak akan berkembang apabila tidak mendapatkan dukungan dari lingkungan. Lingkungan sekolah yang baik, adanya keharmonisan dan kedekatan antar siswa serta guru dapat menghadirkan suasana belajar yang nyaman bagi siswa.

Pada penelitian ini lingkungan sekolah selama proses pembelajaran dilakukan secara daring. Merebaknya virus Covid-19 menyebabkan proses pembelajaran dilakukan secara online. Meskipun pembelajaran dilakukan secara online hasil penelitian ini menunjukkan bahwa variabel lingkungan sekolah memiliki pengaruh signifikan terhadap prestasi belajar. Dalam hal ini menunjukkan semakin baik lingkungan sekolah selama kegiatan belajar online maka akan semakin baik juga prestasi siswa. Sebaliknya semakin jelek atau kurang baik lingkungan sekolah selama kegiatan belajar online maka akan semakin menurunkan prestasi belajar siswa.

Hasil dalam penelitian ini selaras dengan (Supiati, 2020) yang menguraikan hasil lingkungan sekolah mempunyai pengaruh signifikan terhadap prestasi belajar. Sedangkan dalam penelitian yang dilakukan (Gellor, 2019) dikatakan bahwa lingkungan sekolah memiliki pengaruh signifikan terhadap prestasi belajar siswa, selain itu diperoleh data bahwa lingkungan sekolah memiliki pengaruh kuat terhadap prestasi belajar. Penelitian (S. A. L. and Luchivya, 2017) menghasilkan penelitian yang menyatakan bahwa lingkungan sekolah memiliki efek signifikan terhadap prestasi belajar siswa. (Kusnarti, 2019) menyatakan hasil yang berbeda terhadap pengaruh lingkungan sekolah terhadap prestasi belajar, keduanya memiliki pengaruh positif namun tidak signifikan. Pemaparan (Heryyanti et al., 2021) dalam penelitiannya mengatakan bahwa linkungan sekolah dapat berpengaruh terhadap prestasi belajar, karena ligkungan sendiri dapat merubah kebiasaan seseorang menjadi lebih baik ataupun sebaliknya.

Pemaparan beberapa hasil penelitian diatas menegaskan bahwa lingkungan sekolah memiliki pengaruh positif dan signifikan terhadap prestasi belajar siswa.

\section{Pengaruh Self-Efficacy terhadap Prestasi Belajar}

Hasil perhitungan ujit diperoleh nilai signifikansi sebesar 0,479 besar dari 0,05. Dengan demikian $\mathrm{H}_{5}$ ditolak. self-efficacy memiliki pengaruh yang tidak signifikan terhadap prestasi belajar. Penelitian ini selaras dengan penelitian (Rafiola et al., 2020) yang dalam hasil ujinya diperoleh nilai signifikansi 0,366 besar 0,05 sehingga dinyatakan self-efficacy tidak mempunyai pengaruh signifikan terhadap prestasi belajar. Kemudian ada juga penelitian serupa yang dilakukan oleh (Sugiyana, 2015) diperoleh hasil serupa yang menyatakan bahwa self-efficacy tidak mempunyai pengaruh signifikan terhadap prestasi belajar. Pada penelitian ini bisa dikaitkan bahwa prestai belajar tidak selalu didapatkan karena self-efficacy sendiri, melainkan terdapat faktor luar yang dapat berpengaruh terhadap prestasi siswa. Harapan akan suatu hasil tidak selalu dipengaruhi oleh efikasi diri, memungkinkan jika ada siswa yang mempunyai efikasi diri nyang baik akan tetapi tidak dapat memperoleh prestasi yang optimal dikarenakan pemikiran subjektif akan kriteria penilaian guru. Pemikiran bahwa guru tidak menyukai dirinya akan membuat prestasi seorang siswa menjadi rendah. Jadi dalam hal ini guru memiliki peran yang besar dalam mempengaruhi prestasi belajar siswa.

Menurut (Santrock, 2011) self-efficacy seorang siswa tergantung bagaimana guru dalam menginstruksikan siswa-siswanya dalam berprestasi. Bisa jadi siswa memiliki suatu pemikiran positif yang 
334 Pengaruh Lingkungan Sekolah dan Self-Efficacy terhadap Minat Melanjutkan Pendidikan ke Perguruan Tinggi Melalui Mediasi Prestasi Belajar - Heny Eka Sasmi, Achmad Fauzi, Mardi

DOI: https://doi.org/10.31004/edukatif.v4i1.1461

mengarh pada segala sesuatu dapat diperoleh dengan suatu tindakan tertentu, akan tetapi terdapat siswa yang masih kurang percaya terhadap kompetensi yang dimilikinya untuk melakukan tindak tersebut. Sehingga prestasi belajar yang diperoleh tidak sesuai denga napa yang diharapkan. Penelitian yang dilakukan oleh (Husna \& S, 2018) mengatakan bahwa self-efficacy memiliki pengaruh dan kontribusi yang kecil terhadap prestasi belajar siswa. pada penelitian ini diketahui bahwa perolehan hasilnya adalah tidap terdapat pengaruh yang positif signnifikan antara self-efficacy terhdap prestasi belajar. Bertolah belakang dengan hasil tersebut penelitian yang dilakukan oleh (Roebianto, 2020) dan (Tomás et al., 2020) menyatakan bahwa self-efficacy memiliki pengaruh positif dan signifikan terhadap prestasi belajar siswa.

Pemaparan beberapa hasil penelitian diatas menegaskan bahwa self-efficacy memiliki pengaruh positif dan tidak signifikan terhadap prestasi belajar siswa.

\section{Pengaruh Tidak Langsung Lingkungan Sekolah terhadap Minat Melanjutkan Pendidikan ke Perguruan Tinggi Melalui Mediasi Prestasi Belajar}

Berdasarkan perhitungan di atas diketahui bahwa pengaruh langsung pengaruh lingkungan sekolah terhadap minat melanjutkan pneidikan ke perguruan tinggi sebesar 0,072 atau sebesar $7,2 \%$, dan besar pengaruh tidak langsung sebesar 0,049 atau sebesar 4,6\%. Sehingga total pengaruh yang diberikan adalah sebesar 0,121 atau sebesar 12,1\%. Hasil dalam penelitian ini menunjukkan bahwa prestasi belajar mampu memediasi secara sempurna (full mediation) pada variabel lingkungan sekolah terhadap minat melanjutkan pendidikan ke perguruan tinggi melalui mediasi prestasi belajar siswa. hal ini dapat dikeatahui dari hasil perhitungan uji sobel test diperoleh nilai t hitung 2,88 besar dari nilai t tabel 1,98. Prestasi belajar berhasil menjadi mediator dalam mempengaruhi $\mathrm{X}_{1} \mathrm{ke} \mathrm{Y}$.

Besarnya pengaruh tidak langsung lebih rendah dari pengaruh langsung dengan hasil yang signifikan. Disimpulkan $\mathrm{H}_{6}$ diterima, dengan demikian pengaruh lingkungan sekolah terhadap minat melanjutkan pendidikan ke perguruan tinggi melalui mediasi prestasi belajar memiliki pengaruh yang positif dan signifikan. Hasil penelitian ini di dukung oleh (Barokah \& Yulianto, 2019) dimana hasil atas penelitiannya diketahui bahwa variabel lingkungan sekolah terhadap minat studi memapu di mediasi oleh prestasi beajar siswa. Hal tersebut dapat diartikan bahwa lingkungan sekolah yang baik akan memotivasi siswa untuk berprestasi sehingga akan meningkatkan minat siswa untuk lanjut studi ke perguruan tinggi. Sesuai dengan teori konvergensi yang mengatakan bahwa manusia itu unik. Perkembangannya di pengaruhi oleh bagaimana lingkungan yang ada di sekitarnya. Pada pengujian sebeumnya diperoleh hasil X1 tidak berpengaruh terhadap $\mathrm{Y}$, namun dengan adanya variabel mediasi diantara $\mathrm{X} 1$ dan $\mathrm{Y}$ dapat meningkatkan $\mathrm{Y}$ sehingga variabel prestasi belajar mampu memdiasi pengaruh lingkungan sekolah terhadap minat melanjutkan pendidikan ke perguruan tinggi.

Pemaparan beberapa hasil penelitian diatas menegaskan bahwa pengaruh tidak langsung lingkungan sekolah terhadap minat melanjutkan pendidikan ke perguruan tinggi melalui mediasi prestasi belajar memiliki pengaruh signifikan.

\section{Pengaruh Tidak Langsung Self-Efficacy terhadap Minat Melanjutkan Pendidikan ke Perguruan Tinggi Melalui Mediasi Prestasi Belajar}

Berdasarkan perhitungan diketahui bahwa besarnya pengaruh langsung self-efficacy terhadap minat melanjutkan pendidikan ke perguruan tinggi sebesar 0,263 atau sebesar 26,3\%, dan besar pengaruh tidak langsung sebesar 0,015 atau sebesar $1,5 \%$. Sehingga total pengaruh yang diberikan adalah sebesar 0,278 atau sebesar $27,8 \%$. Hasil dalam penelitian ini menunjukkan bahwa prestasi belajar belum mampu memediasi pengaruh self-efficacy terhadap minat melanjutkan pendidikan ke perguruan tinggi melalui mediasi prestasi belajar siswa. hal ini dapat dikeatahui dari hasil perhitungan uji sobel test diperoleh nilai t hitung sebesar 0,22 kecil dari t tabel 1,98. Prestasi belajar belum mampu menjadi mediator dalam mempengaruhi $\mathrm{X}_{2}$ ke $\mathrm{Y}$. 
335 Pengaruh Lingkungan Sekolah dan Self-Efficacy terhadap Minat Melanjutkan Pendidikan ke Perguruan Tinggi Melalui Mediasi Prestasi Belajar - Heny Eka Sasmi, Achmad Fauzi, Mardi

DOI: https://doi.org/10.31004/edukatif.v4i1.1461

Ketidakmampuan prestasi belajar dalam memdiasi variabel self-efficacy ini juga dikarenakan pada saat pengujian tidak adanya pengaruh antara variabel self-efficacy $\left(\mathrm{X}_{2}\right)$ terhadap prestasi belajar $(\mathrm{Z})$.

Besarnya pengaruh tidak langsung lebih rendah dari pengaruh langsung dengan hasil tidak signifikan melihat hasil uji dari sobel tes. Disimpulkan H7 ditolak, dengan demikian pengaruh tidak langsung selfefficacy terhadap minat melanjutkan pendidikan ke perguruan tinggi melalui mediasi prestasi belajar memiliki pengaruh yang positif dan tidak signifikan. Penelitian ini sejalan dengan yang dilakukan oleh (Cahyati \& Muchtar, 2019) yang mana dijelaskan bahwa variabel mediasi prestasi belajar belum mempu mempengaruhi prestasi belajar siswa. hal ini dikarenakan siswa yang memiliki self-efficacy yang baik cenderung tidak memperhatikan prestasi yang dimilikinya. Siswa beranggapan bahwa self-efficacy tanpa harus memperhatikan prestasi dapat menumbuhkan minat serta ketertarikan siswa untuk melanjutkan studi pendidikannya.

Hasil dalam penelitian ini tidak sejalan dengan penelitian yang dilakukan oleh (Barokah \& Yulianto, 2019) yang mana prestasi belajar mampu secara parsial dalam memediasi pengaruh self-efficacy terhadap minat melanjutkan pendidikan pendidikan ke perguruan tinggi. Disebutkan bahwa prestasi yang baik akan meningkatkan kepercayaan diri siswa, melalui prestasi pula akan meningkatkan minat siswa untuk melanjkutkan studi.

Pemaparan beberapa hasil penelitian diatas menegaskan bahwa pengaruh tidak langsung self-efficacy terhadap minat melanjutkan pendidikan ke perguruan tinggi melalui mediasi prestasi belajar memiliki pengaruh signifikan.

\section{KESIMPULAN}

Berdasarkan hasil penelitian yang telah dipaparkan di atas disimpulkan 1) lingkungan sekolah memiliki pengruh positif dan tidak signifikan terhadapp minat melanjutkan pendidikan ke perguruan tinggi, 2) selfefficacy dan prestasi belajar memiliki pengaruh positif dan signifikan terhadap minat melanjutkan pendidikan ke perguruan tinggi, 3) lingkungan sekolah memiliki pengaruh positif signifikan terhadap prestasi belajar, 4) self efficacy memiliki pengaruh positif dan tidak signifikan terhadap prestasi belajar. 5) lingkungan sekolah memiliki pengaruh tidak langsung dan tidak signifikan terhadap minat melanjutkan pendidikan ke perguruan tinggi melalui mediasi prestasi belajar, 6) self-efficacy memiliki pengaruh tidak langsung dan signifikan erhadap minat melanjutkan pendidikan ke perguruan tinggi melalui mediasi prestasi belajar.

\section{DAFTAR PUSTAKA}

Agustina, R. (2018). Pengaruh Motivasi Belajar, Prestasi Belajar, Status Sosial Ekonomi Orang Tua, Dan Lingkungan Teman Sebaya Terhadap Minat Melanjutkan Pendidikan Ke Perguruan Tinggi S1 Akuntansi Pada Siswa Smk Swasta Di Banjarmasin. Dinamika Ekonomi Jurnal Ekonomi Dan Bisnis, 11(1), 12-27.

Amiqul, I. Dan S. Dalam H. M., \& Rediana, S. (2016). Pengaruh Prestasi Belajar, Kondisi Sosial Ekonomi Orang Tua Dan Self Efficacy Terhadap Minat Melanjutkan Studi Ke Perguruan Tinggi Siswa Ips. Economic Education Analysis Journal, 5(3), 1034-1045.

Bandura, A. (1995). Self-Efficacy In Changing Societies (Pertama). Cambridge University Press.

Barokah, N., \& Yulianto, A. (2019). Pengaruh Lingkungan Sekolah, Self Efficacy, Dan Status Sosial Ekonomi Orang Tua Terhadap Minat Melanjutkan Pendidikan Tinggi Dengan Prestasi Belajar Sebagai Variabel Mediasi. Jurnal Pendidikan Dan Ekonomi, 8(2), 434-452. Https://Doi.Org/10.15294/Eeaj.V8i2.31498

Cahyati, R., \& Muchtar, B. (2019). Pengaruh Lingkungan Keluarga, Teman Sebaya, Dan Prestasi Belajar Terhadap Minat Melanjutkan Pendidikan Ke Perguruan Tinggi Siswa Smk Negeri Bisnis Dan Manajemen Kota Padang. Jurnal Ecogen, 2(3), 483. Https://Doi.Org/10.24036/Jmpe.V2i3.7420

Defriyanto, D., \& Sugiharta, I. (2020). Correlation Of Self-Efficacy With Decision Making Continuing 
336 Pengaruh Lingkungan Sekolah dan Self-Efficacy terhadap Minat Melanjutkan Pendidikan ke Perguruan Tinggi Melalui Mediasi Prestasi Belajar - Heny Eka Sasmi, Achmad Fauzi, Mardi DOI: https://doi.org/10.31004/edukatif.v4i1.1461

Studies In Students At Islamic Based Universities. Konseli: Jurnal Bimbingan Dan Konseling (EJournal), 7(1), 07-12. Https://Doi.Org/10.24042/Kons.V7i1.6114

Faliyandra, F. (2019). Tri Pusat Kecerdasan Sosial Membangun Hubungan Baik Antar Manusia Pada Lingkungan Pendidikan Di Era Teknologi (A. Ariyanto (Ed.)). Literasi Nusantara Abadi.

Gellor, J. P. (2019). A Structural Model Of Academic Buoyancy, Aptitude, And School Environment On The Mathematics Achievement Of Pre-Service Teachers. Journal Of Education In Black Sea Region, 4(2), 96-115. Https://Doi.Org/10.31578/Jebs.V4i2.173

Hanim, L. F., \& Puspasari, D. (2021). Edukatif: Jurnal Ilmu Pendidikan Pengaruh Self Efficacy Terhadap Minat Melanjutkan Studi S2 Pada Mahasiswa Prodi Pendidikan Administrasi Perkantoran. 3(4), 18381848.

Heryyanti, D. A., Tanzeh, A., Masrokan, P., \& Tulungagung, I. (2021). Edukatif: Jurnal Ilmu Pendidikan Pengaruh Gaya , Minat, Kebiasaan Dan Lingkungan Belajar Terhadap Prestasi Belajar Siswa Madrasah Ibtidaiyah Di Era New Normal. 3(6), 3935-3945.

Husna, R., \& S, B. Y. (2018). Pengaruh Self Efficacy Terhadap Hasil Belajar Matematika Siswa Di Kelas X Smk Smti Banda Aceh. Jurnal Ilmiah Mahasiswa Pendidikan Matematika, 3(2), 43-48.

Kurniawati, Y. G. B. (2015). Pengaruh Pendapatan Orangtua, Perhatian Orangtua, Dan Fasilitas Di Rumah Terhadap Prsetasi Belajar Siswa. Kresna Bina Insan Prima.

Kusnarti, G. (2019). The Influenze Of Students Perceptions Of School Environment And Learning Discipline Tpward The Achievement Of English Subject. 2(1), 54-59.

Kustiani, K. P., Sugiharto, D. Y. P., \& Anni, C. T. (2019). Minat Studi Lanjut Ke Perguruan Tinggi Siswa Ditinjau Dari Self-Efficacy Dan Aspirasi Orangtua. Psychocentrum Review, 1(1), 17-26. Https://Doi.Org/10.30998/Pcr.115

Lase, I. P. S. (2020). Pengaruh Tingkat Pendapatan Orang Tua, Tingkat Pendidikan Orang Tua, Lingkungan Teman Sebaya Dan Efikasi Diri Terhadap Minat Siswa Untuk Melanjutkan Keperguruan Tinggi Smk Kabupaten Nias. 8(2), 261-264.

Mahyudin, M. (2019). Faktor-Faktor Yang Mempengaruhi Minat Siswa Melanjutkan Pendidikan Tinggi Ke Universitas Terbuka (Studi Kasus Slta Negeri Dan Swasta Sederajat Di Provinsi Jambi). Jurnal Ilmiah Dikdaya, 9(1), 32. Https://Doi.Org/10.33087/Dikdaya.V9i1.122

Megawanti, P., Megawati, E., \& Nurkhafifah, S. (2020). Persepsi Peserta Didik Terhadap Pjj Pada Masa Pandemi Covid-19. Jurnal Ilmiah Pendidikan, 7(2), 75-82.

Nurjannah, L. A., \& Kusmuriyanto. (2016). Pengaruh Prestasi Belajar, Motivasi Belajar, Kondisi Sosial Ekonomi Orang Tua Dan Lingkungan Sosial Terhadap Minat Melanjutkan Ke Perguruan Tinggi. Economic Education Analysis Journal, 5(2), 495-504.

Priyono. (2008). Metode Penelitian Kuantitatif (T. Chandra (Ed.); Kedua). Zifatama Publishing.

Puspitaningtyas, A. W. K. Dan Z. (2012). Metode Penelitian Kuantitatif. Pandiva Buku.

Qahfi, M., Apuanor, \& Sudarmono. (2020). Student Interest In Continuing Study. 27(Icosheet 2019), 83-85. Https://Doi.Org/10.2991/Ahsr.K.200723.020

Rafiola, R. H., Setyosari, P., Radjah, C. L., \& Ramli, M. (2020). The Effect Of Learning Motivation, SelfEfficacy, And Blended Learning On Students' Achievement In The Industrial Revolution 4.0. International Journal Of Emerging Technologies In Learning, 15(8), 71-82. Https://Doi.Org/10.3991//jet.V15i08.12525

Rahayu, I. (2019). The Influence Of Motivational Learning, Learning Achievemnet, Parental Socio-Economic Status, And School Environment On Interest In Continuing Education To Universities In Vocational High School Student In Indonesia. Http://Library1.Nida.Ac.Th/Termpaper6/Sd/2554/19755.Pdf

Riyadi, I. (2019). Model Pembelajaran Berbasis Metakognisi Untuk Peningkatan Kompetensi Siswa Pada 
337 Pengaruh Lingkungan Sekolah dan Self-Efficacy terhadap Minat Melanjutkan Pendidikan ke Perguruan Tinggi Melalui Mediasi Prestasi Belajar - Heny Eka Sasmi, Achmad Fauzi, Mardi

DOI: https://doi.org/10.31004/edukatif.v4i1.1461

Mata Pelajaran Ips. Deepublish.

Roebianto, A. (2020). The Effects Of Student's Attitudes And Self-Efficacy On Science Achievement. Jurnal Pengukuran Psikologi Dan Pendidikan Indonesia (Jp3i), 9(1), 1-10. Https://Doi.Org/10.15408/Jp3i.V9i1.14490

S. A. L. And Luchivya, R. O. (2017). School-Environment And Its Effects On The Academic Achievement On Girls In Secondary Education : A Case Of Kisumu East Sub-County. 2(2), 46-55.

Sakdiah, H. (2018). Factors Influencing The Students' Interests In Continuing Their Education To University. Jurnal Pendidikan Progresif, 8(2), 81-89. Https://Doi.Org/10.23960/Jpp.V8.I2.201809

Santrock, J. W. (2011). Live Span (Perkembangan Hidup). Erlangga.

Saputra, T. W. P. R. (2015). Hubungan Status Ekonomi Orang Tua Dan Pestasi Belajar Otomotif Dengan Minat Melanjutkan Pendidikan Ke Perguruan Tinggi Siswa Kelas Xi Program Keahlian Teknik Otomotif Smk Perindustrian Yogyakarta Tahun Pelajaran 2014/2015. 573-584.

Siti Khadijah, Henny Indrawati, S. (2017). Analisis Minat Peserta Didik Untuk Melanjutkan Pendidikan Tinggi. 26, 178-188.

Slameto. (2019). Partisipasi Orangtua Dan Faktor Latar Belakang Yang Bepengaruh Terhadap Prestasi Belajar Siswa (Q. M. Partner (Ed.)). Cv.Penerbit Qiara Media.

Sofiyanti, U. \& S. (2019). Minat Melanjutkan Pendidikan Ke Perguruan Tinggi: Studi Empiris Tentang Pengaruh Mediasi Prestasi Belajar. Economic Education Analysis Journal, 8(2), 453-469. Https://Doi.Org/10.15294/Eeaj.V8i2.31500

Subarkah, A., \& Nurkhin, A. (2018). Pengaruh Status Sosial Ekonomi Orang Tua, Efikasi Diri, Dan Bimbingan Karier Terhadap Minat Melanjutkan Ke Pendidikan Tinggi Pada Siswa Sma Negeri 1 Kejobong. Jurnal Pendidikan Dan Ekonomi, $4(2), \quad 400-414$. Http://Journal.Unnes.Ac.Id/Sju/Index.Php/Eeaj\%0apengaruh

Sugiyana, S. (2015). Pengaruh Self-Regulated Learning, Self-Efficacy Dan Perhatian Orangtua Terhadap Prestasi Belajar Matematika Siswa. Psikopedagogia Jurnal Bimbingan Dan Konseling, 4(1), 63. Https://Doi.Org/10.12928/Psikopedagogia.V4i1.4497

Sugiyono. (2013). Metodelogi Penelitian Kuantitatif Kualitatif Dan R\&D. Alfabeta Bandung.

Supiati. (2020). Pengaruh Jejaring Sosial, Lingkungan Sosial Dan Motivasi Belajar Terdap Prestasi Belajar Ekonomi Pada Jurusan Ips Sma Negeri Di Kabupaten Polewali Mandar. 1(1), 42-53.

Susanto, A. (2016). Teori Belajar Dan Pembelajaran Di Sekolah Dasar. Prenadamedia Group.

Tomás, J. M., Gutiérrez, M., Georgieva, S., \& Hernández, M. (2020). The Effects Of Self-Efficacy, Hope, And Engagement On The Academic Achievement Of Secondary Education In The Dominican Republic. Psychology In The Schools, 57(2), 191-203. Https://Doi.Org/10.1002/Pits.22321

Tri Anjaswari, Nursalam, Widati S, Y. (2019). Deteksi Dini Potensi Kenakalan Remaja (Juvenile Delinquency) Dan Solusi. Zifatama Jawara.

Yuniarti. (2017). Pengaruh Pendapatan Orang Tua, Lingkungan Sosial Dan Informasi Perguruan Tinggi Terhadap Minat Melanjutkan Pendidikan Ke Perguruan Tinggi Pada Siswa Kelas Xi Ips Madrasah Aliyah Nu 01 Limpung Kabupaten Batang. Economic Education Analysis Journal, 6(3), 843-853 